$273^{\circ} \pm 150$ BC (BM-49) [3]. Second, they provide a minimum age for the Neolithic ploughmarks on the site [4]. These are associated with a phase of forest clearance. As similar evidence [5] has been obtained from the Windmill Hill Long Barrow, $3240 \pm 15^{\circ}$ BC (BM-180) [6], and Wayland's Smithy (date above) it appears that forest clearance was taking place on the Chalk of North Wiltshire and Berkshire early in the 3 rd millennium BC. Third, the dates provide a maximum age for an assemblage of Middle Neolithic pottery stratified in the upper levels of the primary fill of the ditches. This is of Ebbsfleet/Mortlake tradition. Its stratigraphical position makes it unlikely that its age is significantly younger than the dates quoted. These can be compared with dates for similar assemblages from Windmill Hill causewayed enclosure, $257^{\circ} \pm \mathrm{I} 5^{\circ} \mathrm{BC}$ (BM-74) [7] and from Northfleet, Kent,
$2710 \pm$ I50 BC (BM-II3) [8]. Finally, the dates provide a comparison of three kinds of sample material-charcoal, bone and antlerwhich were stratigraphically contemporary. Only the protein fractions of the bone and antler were used [9]. The dates are indistinguishable within the limits of their probable errors. J. G. EVANS and R. BURLEIGH

[r] ANTIQUITY, 1968, 138.

[2] ANTIQUITY, 1965, 126 .

[3] Radiocarbon, 2, 1960, 26.

[4] ANTIQUITY, 1967, 289.

[5] Evidence from land molluscan analysis. Windmill Hill Long Barrow, Evans, unpublished; Wayland's Smithy, information from M. P. Kerney.

[6] ANTIQUITY, I966, 299.

[7] I. F. Smith, Windmill Hill and Avebury: Excavations by Alexander Keiller, 1925-1936 (Oxford, 1965), ir.

[8] Radiocarbon, 5, 1963 , 104.

[9] Nature, 213, 1967, 415.

\title{
Neolithic Pottery Production in Cornwall
}

Recent petrological work on pre-Roman Iron Age pottery (Peacock, 1968, and forthcoming) has shown that the examination of potsherds in thin section under the petrological microscope can provide information of value in assessing the organization of pottery production in prehistoric Britain. Unfortunately, studies of this kind have not been so extensive with material of earlier periods, but nevertheless there is a growing body of data about Neolithic pottery from which it is possible to make some preliminary deductions.

Undoubtedly, the bulk of Neolithic pottery was produced and used locally: Hodges's work on the Neolithic wares from Windmill Hill points to a local clay source for about 69 per cent of the vessels (Smith, I965, 43), while Thomas's study of the Hembury pottery showed that the predominant, coarse, 'a' ware contains fragments of flint, chert and quartz all of which could have been obtained in the vicinity of the site (Liddle, I935, I62). Further evidence is provided by the heavy mineral analysis of a Middle Neolithic sherd from Warwick, which yielded a suite of minerals comparable with that from the Triassic rocks of the area (Peacock, 1967,98 ). To this we could perhaps add Zeuner's analysis of shell fragments in late Neolithic grooved ware found near Cambridge (Frere, 1943, 4I), and Sandford's opinion on the origins of the shells in pottery from the Abingdon causewayed camp (Case, 1956, 19), both of which are in accordance with a local origin.

However, for some time, it has been apparent that the materials for several types of pottery common in south and south-western England were obtained at some distance from their find-sites. Most abundant are the vessels containing fossil shell and oolite derived from the Jurassic outcrop, perhaps in the BathFrome region. These constitute about 30 per cent of the pottery at Windmill Hill (Smith, $1965,46)$, I7 per cent of the vessels from Robin Hood's Ball, near Shrewton (Thomas, 1964, I4), and are known from other sites in Wiltshire such as Whitesheet Hill, Knap Hill and the West Kennet long barrow.

Shell in the late Neolithic grooved ware from Woodhenge, was examined by Davy (Cunnington, 1929, 75) but this is apparently of marine origin. 


\section{ANTIQUITY}

Another group clearly imported to the findsite is the Hembury ' $f$ ' ware, characterized by fragments of igneous origin. This was originally studied by $\mathrm{H}$. H. Thomas (Liddle, I929-32, 92 and I75) who suggested a metamorphic source on the edge of the Dartmoor granite massif. Cornwall and Hodges (1964) extended this work by showing that similar pottery is to be found at Maiden Castle, Windmill Hill (Smith, 1965, 44) and Robin Hood's Ball (Thomas, 1964, I9) but they followed H. H. Thomas in their assessment of the source of the raw materials. The present writer has long felt that the distinctive petrological features of this ware should enable greater precision in the definition of the source and hence yet another study has been undertaken.

\section{PETROLOGY AND SOURCE}

In thin section, the main characteristics of the pottery are relatively large angular grains of felspar, amphibole and quartz set in a finer matrix comprising these minerals in optically anisotropic fired clay. The felspar is usually turbid and intensely altered, though some fresh twinned plagioclase grains are present, while the amphibole is frequently of a pale green or colourless variety. These minerals must derive from the weathering of an altered igneous rock since artificial crushing would result in many polymineralic rather than monomineralic fragments, as already noted by Cornwall and Hodges (1964, 3r). Although quartz is present in all sections, it is comparatively scarce and does not occur in the quantities one would anticipate had the material been derived from acid igneous rocks. Furthermore the grain size suggests that a plutonic rock was involved. Thus the provenance of the raw materials should be in an area of somewhat altered basic or intermediate plutonic rocks and the only possible source in south-western England is the gabbro which outcrops over about seven square miles of the Lizard Head in Cornwall. This rock weathers in places to form a yellow clay with abundant mineral fragments (Flett, 1946, 78-89) and examination in thin section demonstrates that it is mineralogically identical with the pottery.
The writer has no doubt that this was used in pottery making and it is clear that the coarse mineral fragments are a natural constituent of the clay rather than an added filler as previously thought. The clay was an important source in the Iron Age (see Peacock, forthcoming) and probably in other periods as well, but this problem is being studied in more detail.

\section{DISCUSSION}

FIGURE I shows the distribution of Neolithic vessels made of gabbroic clay from the Lizard. The proportions are based on examination of sherds under a hand-lens supplemented by thin sections in cases of doubt, and use of published information when the original material could not be located. Throughout the extraordinarily broad distribution (approaching 200 miles) the vessels form a typologically homogeneous group. The principal forms are the simple open bowl with unexpanded rim (e.g. Liddle, 1929-32, P. 133) and the carinated bowl (e.g. Patchett, I944, fig. I, F), both with thin walls and usually finished with burnishing. Carefully executed trumpet lugs are a characteristic feature of the former type (e.g. Liddle, 1929-32, P, 133; 1935, P. 366 and P. 429) but vertically perforated examples are occasionally found on the latter (e.g. Patchett, I944, fig. I, E, F; Liddle, 1929-32, P. 293), though one example from Corfe Mullen occurs on what appears to have been an open bowl (Calkin and Piggott, 1938, no. I r). Simple 'D' shaped solid lugs are known from Carn Brea (Patchett, 1944, fig. I, C), and a single example of a curious unperforated knob-shaped type is in the Hembury collection (Liddle, I935, P. 332).

The restricted typology of this group is important since it precludes distribution of raw materials rather than finished pots. Had the vessels been made on the find-sites the homogeneity is unlikely to have been preserved due to the influence of predominant local types. This is confirmed by the petrology since the clay never contains erratics such as flint which might have been incorporated occasionally had the vessels been made for example in Wessex, from imported material.

If the pots were transported from Cornwall 


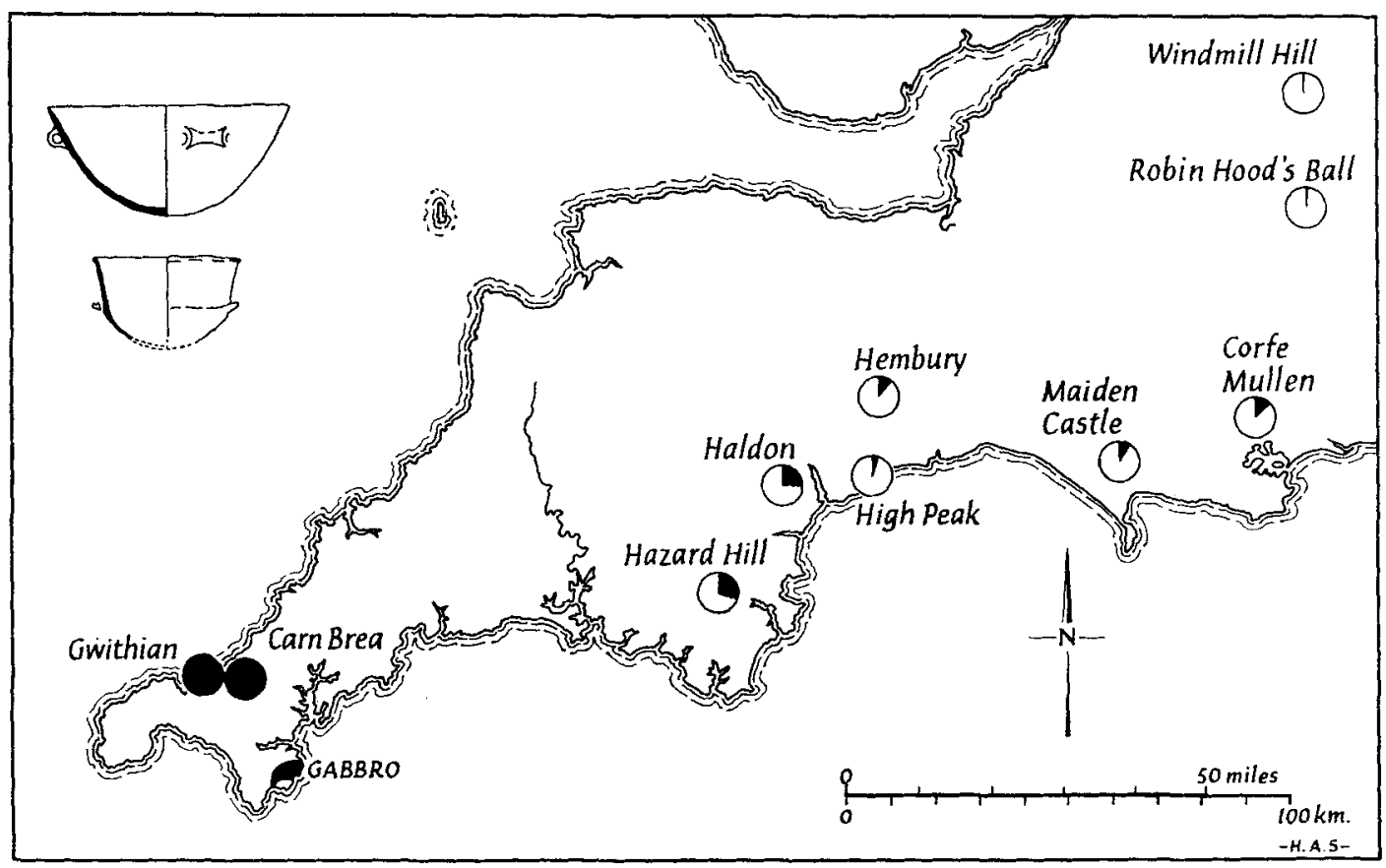

Fig. I. Map showing the source and distribution of Neolithic pottery made from the gabbroic clay of the Lizard Head. Based on information recorded in the catalogue of sites ( $p .148)$; the black sectors in the circles represent the proportion of vessels from the Lizard. It should be noted that the estimates for Gwithian, Carn Brea, Haldon and Corfe Mullen are based on small samples ( 15 vessels or less)

throughout south-western England and into Wessex, we must consider the mechanism by which this was effected. In the past it has been customary to regard Neolithic pottery as an essentially personal product and to equate the occurrence of exotic wares on a site with occasional visits by people from elsewhere (Piggott, 1954, 30; Smith, 1965, 6o; Clark, I952, 251). However, in this case it now seems more reasonable to postulate trade as a means of dispersal. A measure of support comes from the pots themselves since in technique they are well above the general run of British Neolithic ceramics and have the appearance of competent specialist products. This is well illustrated by the trumpet lugs which occur in both local and imported fabrics on sites such as Hembury and Maiden Castle. Those in the

* This can be compared with Clark's (1952, 25I) suggestion that had the exotic pottery from Köln- local fabrics are blatant copies of the Cornish imports being much less carefully executed and sometimes of the solid form which does not occur in the imported material. The distribution is also of interest in this respect since it follows closely that of Cornish stone axes (cf. Evens et al., 1962, figs. 1, 2, 5) and there seems no reason why the pottery could not have been traded along with some of the earlier axe groups such as XVI and XVII.*

There are thus grounds to believe that pottery was being produced in Cornwall on the Lizard Head perhaps as early as $c .3300$ $3000 \mathrm{BC}$, to judge from the Hembury (Fox, 1963) and High Peak (Pollard, 1967) radiocarbon dates, and trade in this ware seems to have influenced the development of Neolithic ceramics far to the east.

Lindenthal been due to trade, its arrival should have been accompanied by stone axes. 


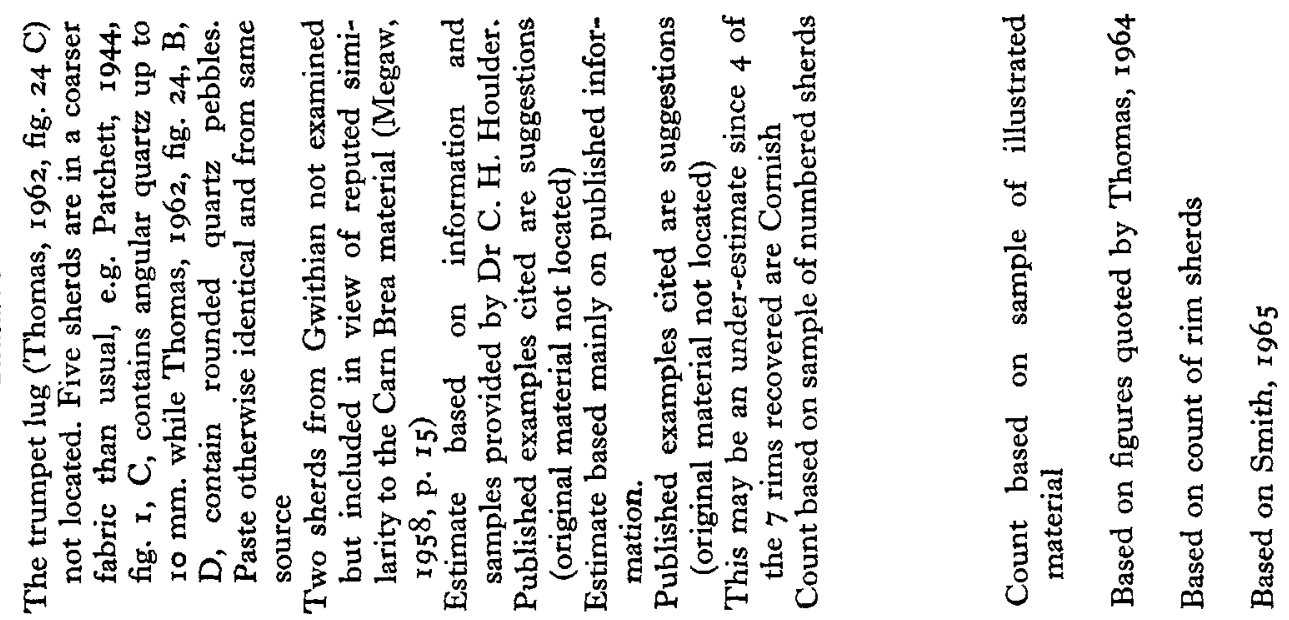
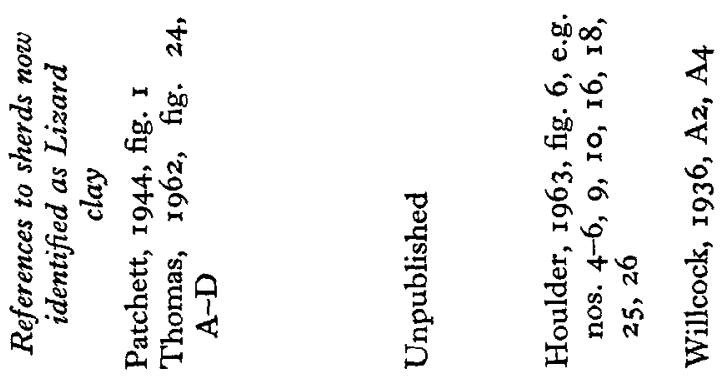

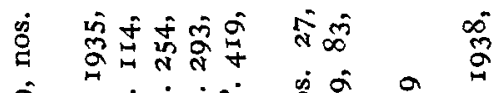

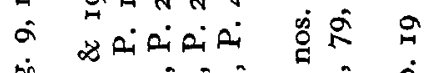

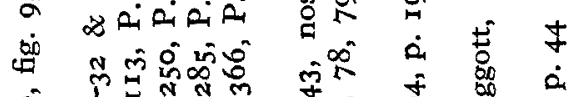

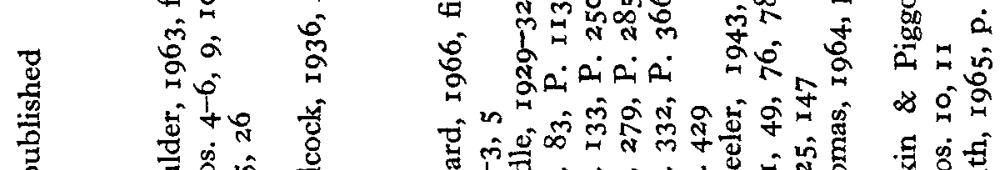

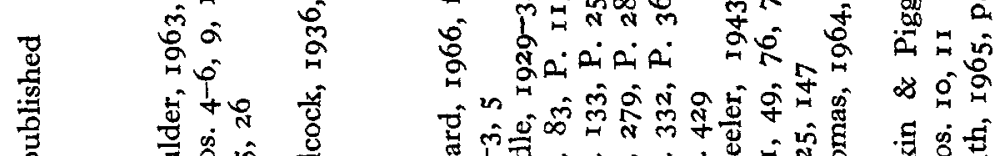

$\frac{0}{\sqrt{3}} \frac{0}{3}$
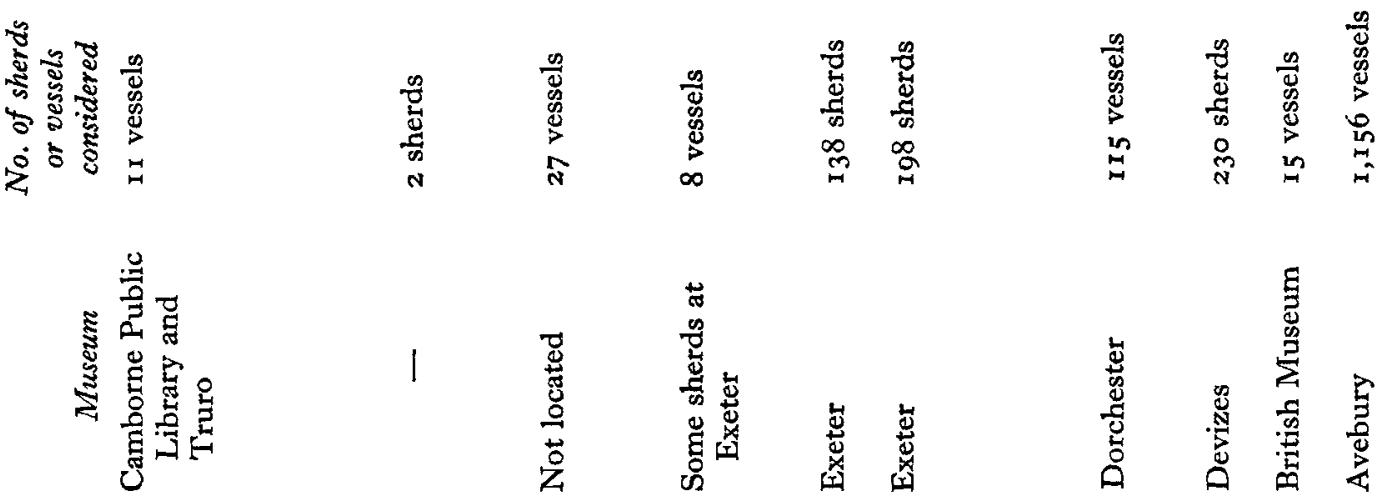

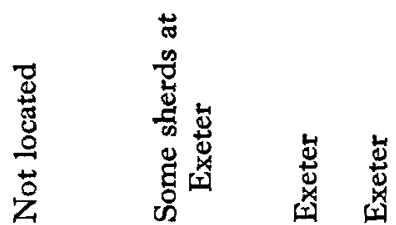

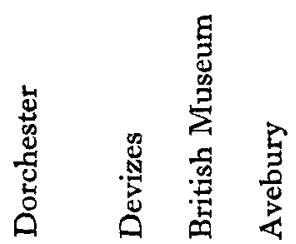

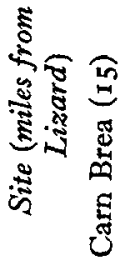

亿ู

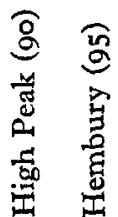

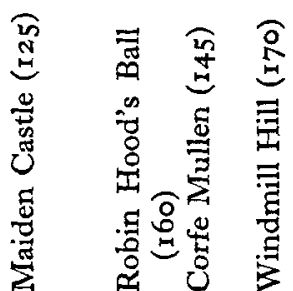




\section{NOTES AND NEWS}

\section{ACKNOWLEDGEMENTS}

The work outlined above was conducted as part of a programme to study the petrology of prehistoric and later ceramics from southern and south-western Britain, with financial assistance from the Goldsmith's Company, the Leverhulme Trust and the University of Southampton, here gratefully acknowledged.
The curators of the collections at the British Museum, Camborne, Dorchester, Exeter and Truro, afforded the writer every facility in the study of their material and help was received from Dr C. H. Houlder. The writer is indebted to Mr A. M. ApSimon for his helpful criticism of a draft of this note. D. P. S. PEACOCK

\section{BIBLIOGRAPHY}

CALKIN, J. B. and PIGGotT, s., 1938. 'A Neolithic "A" Habitation site at Corfe Mullen', Proc. Dorset NH and Arch. Soc., LX, 73.

CASE, H. I 956. 'The Neolithic Causewayed Camp at Abingdon, Berks', Ant. $\mathcal{F}$., xxxvı, I I.

CLARK, J. G. D. I952. Prehistoric Europe, The Economic Basis (London).

CORNWALl, I. W. and HoDges, H. W. M. I964. 'Thin sections of British Neolithic Pottery: Windmill Hill-A Test Site', Bull. Inst. Arch. London Univ., IV, 29.

CUNNINGTON, M. E. 1929. Woodhenge (Devizes).

EVENS, E. D., GRINSELL, L. V., PIGGOTT, S. and WALlIS, F. S. 1962. Fourth Report of the Sub-Committee of the South-western Group of Museums and Art Galleries on the Petrological Identification of Stone Axes. Proc. Prehist. Soc., Xxvin, 209.

FLETT, J. S. 1946. The Geology of Lizard and Meneage (Mem. Geol. Surv. Great Britain).

Fox, A. 1963. 'Neolithic Charcoal from Hembury', ANTIQUITY, 228.

FRERE, D. H. S. I943. 'Late Neolithic Grooved Ware near Cambridge', Ant. F., xxIII, 34 .

HOULDER, C. H. 1963. 'A Neolithic Settlement on Hazard Hill, Totnes', Proc. Devon Arch. Expl. Soc., no. $21,2$.

LIDDLE, D. M. I929-32. 'Excavations at Hembury Fort, Devon', Proc. Devon Arch. Expl. Soc., I. Three annual reports: 40, 90, I62.

1935. Excavations at Hembury Fort, Devon. Proc. Devon Arch. Expl. Soc., II, 135.
MEgaw, J. v. s. $195^{8}$. 'The Neolithic Period in Cornwall', Proc. West Cornwall FC, II, no. 2, 13.

PATChetT, F. M. I944. 'Cornish Bronze Age Pottery', Arch. F., CI, 29.

PEACOCK, D. P. S. I967. 'The Heavy Mineral Analysis of Pottery: A Preliminary Report', Archaeometry, $\mathrm{x}, 97$.

1968. 'A Petrological Study of Certain Iron Age Pottery from Western England', Proc. Prehist. Soc., XxxIv, 4I4.

Forthcoming. 'A Contribution to the Study of Glastonbury Ware from South-Western Britain', Ant. F., XLIX, r 969 .

PIGGo'T, s. 1954. Neolithic Cultures of the British Isles (Cambridge).

POLLARD, S. H. M. I966. 'Neolithic and Dark Age Settlements on High Peak, Sidmouth, Devon', Proc. Devon Arch. Expl. Soc., no. 23, 35.

1967. 'Radiocarbon dating of Neolithic and Dark Age Settlements on High Peak, Sidmouth, Devon', Proc. Devon Arch. Soc., no. 25, 41.

smith, I. F. 1965. Windmill Hill and Avebury. Excavations by A. Keiller (Oxford).

тhomas, A. C. 1962. 'Carn Brea Finds in Camborne Public Library', Cornish Arch., 1, 104.

THOMAs, N. I964. 'The Neolithic Causewayed Camp at Robin Hood's Ball, Shrewton', Wilts. Arch. Mag., LIX, I.

WHEELER, R. E. M. 1943. Maiden Castle, Dorset (Rep. Res. Comm. Soc. Ant. London), 12.

WILlCoCK, E. H. 1936. 'A Neolithic Site on Haldon', Proc. Devon Arch. Expl. Soc., II, 244.

\section{Corrections to ANTrQUiTy, March 1969:}

'Radiocarbon Dates and the Scottish Iron Age', p. ז6, col. I:

lines 23-5 should read: 'This conversion is achieved by multiplying the absolute age (pre1950) by $1 \cdot 03 . '$

line 30 should read: ' 60 years older'.

'A Foundation Sacrifice at Birkenhead Priory', pp. $5^{6}$ and 57:

Mrs N. F. McMillan and the Editor regret that owing to a misunderstanding the name of the late $\mathrm{Mr} \mathrm{W}$. Fergusson Irvine was misspelt. 